\title{
Development of Social Cost and Benefit Analysis (SCBA) in the Maqūsid Shariah Framework: Narratives on the Use of Drones for Takaful Operators
}

\author{
Amirul Afif Muhamat ${ }^{1, * \mathbb{D}}$, Ahmad Farouk Zulkifli ${ }^{1}$, Suzana Sulaiman ${ }^{2}$, Geetha Subramaniam ${ }^{3}$ and \\ Saadiah Mohamad ${ }^{4}$ \\ 1 Faculty of Business and Management, Universiti Teknologi MARA (Selangor Campus), \\ Puncak Alam 42300, Malaysia; ahmadfaroukzulkifli@gmail.com \\ 2 Faculty of Accountancy, Universiti Teknologi MARA (Selangor Campus), Puncak Alam 42300, Malaysia; \\ suzana1110@uitm.edu.my \\ 3 Graduate School of Business, SEGi University, Kota Damansara, Petaling Jaya 47810, Malaysia; \\ geethasubramaniam@segi.edu.my \\ 4 Faculty of Business and Accountancy, Universiti Selangor, Shah Alam 40450, Malaysia; \\ saadiahmohamad@unisel.edu.my \\ * Correspondence: amirulafif@uitm.edu.my
}

Citation: Muhamat, Amirul Afif, Ahmad Farouk Zulkifli, Suzana Sulaiman, Geetha Subramaniam, and Saadiah Mohamad. 2021. Development of Social Cost and Benefit Analysis (SCBA) in the Maqāșid Shariah Framework: Narratives on the Use of Drones for Takaful Operators. Journal of Risk and Financial Management 14: 387. https://doi.org/10.3390/jrfm14080387

Academic Editor: Md. Hafij Ullah

Received: 9 June 2021

Accepted: 9 August 2021

Published: 19 August 2021

Publisher's Note: MDPI stays neutra with regard to jurisdictional claims in published maps and institutional affiliations.

Copyright: (c) 2021 by the authors. Licensee MDPI, Basel, Switzerland. This article is an open access article distributed under the terms and conditions of the Creative Commons Attribution (CC BY) license (https:// creativecommons.org/licenses/by/ $4.0 /)$

\begin{abstract}
Takaful operators are part of the Islamic financial institutions that are expected to achieve the commercial and social objectives by their stakeholders particularly the takaful participants (policyholders). First, this study aims to postulate a new framework to measure cost effectiveness by including the social and economic benefits of drone-assisted technology in the context of maquasid Shariah. Second, the study intends to investigate how the takaful industry can benefit from the drone-assisted technology, particularly in terms of cost reduction. This paper presents an early finding that forms part of a bigger research project which is focusing on the use of drone for disaster victim identification (DVI). This study employs thematic analysis of qualitative research method by engaging key informants who are Shariah expert, drone practitioner and accounting expert. In the context of emerging economies like Malaysia, the adoption of drone is sporadic when some industries such as military and agriculture are quite experienced with it; but for the takaful sector is almost none. This study provides preliminary findings that suggests there is potential of cost effectiveness for drone usage from the perspectives of SCBA in the maqūsid Shariah framework. The main contributions from this paper are: (1) the new SCBA framework derived from the maqāsid Shariah perspective and, (2) the application of this framework in examining the cost effectiveness on the use of drones by the takaful operators especially during disaster.
\end{abstract}

Keywords: Shariah; social cost benefits analysis; SCBA; drone; maqāṣid

\section{Introduction}

Located in Southeast Asia, Malaysia experiences tropical climate all year round. Malaysia is geographically located outside the Pacific Ring of Fire, making it relatively free from severe natural disasters such as earthquake and volcano eruption found in neighbouring countries like Indonesia and the Philippines. Nevertheless, the effects of climate changes have caused Malaysia to be vulnerable to certain natural disasters such as floods, landslides, forest fires, haze and epidemics (Center for Excellence in Disaster Management \& Humanitarian Assistance 2016). For example, the heavy floods during the end of 2014 were the worst floods that ever happened in the Malaysian history affecting more than 100,000 people with 21 deaths recorded (Reuters 2014).

Hence, disaster management is a top priority for the Malaysian government. Disaster management is crucial to reduce damages and loss of life due to mass disasters. Disaster management in Malaysia which was previously held under the jurisdiction of National 
Security Council (NSC) has now been taken over by the Prime Minister's Department with the setting up of a new National Disaster Management Agency, NADMA (HAKAM 2015).

Mass disaster management requires fast and efficient deployment of assets that can be used during search and rescue missions and disaster victim identification (DVI). There are great potentials of using drone-assisted technology in disaster management (Reich 2016). However, the use of asset, particularly drones, in disaster management has several cost implications. In order to justify the investment in the development of high technology drone, cost effectiveness study is required to determine its effectiveness compared to current conventional procedure of DVI (George 2016).

Using the existing cost effectiveness model, the cost (both financial and non-financial) of DVI processes using current conventional procedure and drone-assisted technology can be compared. However, certain technology or deployment of certain assets may not be sufficiently justified by using only the existing cost effectiveness model. The use of new technology may give rise to other social costs and benefits which are not taken into account when using the existing cost effectiveness model (Levin and McEwan 2001).

An Islamic discourse on maqasid Shariah (objectives of Shariah) and maslahah (public interest) point to the need to consider the objectives of alleviating harm and providing maximum benefits to the people in any policy intervention or product development. There has been an in-creasing interest in this maqasid-based approach especially in Islamic finance and this has encouraged the thinking beyond profitability and to consider the needs of various stakeholders rather than just the interest of the company and its shareholders (Dusuki and Abdullah 2007; Saba 2017).

Hence, a more comprehensive cost effectiveness study in the use of drone technology is required as this is can be used not only for commercial profit-making activities but also as a tool for disaster management with high national importance where the issue of maqasid Shariah and maslahah are overriding. Thus, by using existing social cost-benefit model with inputs from the Islamic perspective, it is possible that the modified model can render a certain intervention or use of new technology to be more cost effective in a wider maqasid-based perspective. Currently, there is lack of discussion in this area that uses the Islamic maqasid-based approach to measure the social cost and benefit of a technological intervention, making this research a pioneering work.

A discourse on maqasid Shariah has also reached the commercial profit-making activities of the Islamic finance industry. Cost reduction is still very much a concern in an industry where the Islamic financial institutions have to compete with their conventional counterparts. In the context of takaful industry, while the potential is great, the adoption rate of takaful policy is still low (Ibrahim et al. 2015). Takaful is an Islamic insurance system that derives its principles from the teachings of Islam or interchangeably being referred as Shariah. This alternative protection scheme to conventional insurance distinguishes itself by avoiding the prohibited elements namely the riba or interest-based transaction, excessive uncertainty or gharar and gambling which is also known as maysir (Muhamat and McIver 2019).

The takaful industry has to improve its overall efficiency by improving its claims process which is very crucial for the competitiveness in this industry. So, one of the ways for takaful operators to improve is by incorporating the latest technology in their operations. This study aims to explore on one of the emerging issues in takaful which is on the technology adoption by the takaful operators.

First, this study postulates a new framework to measure cost effectiveness to include the social and economic benefits of drone-assisted technology in DVI derived from the social cost and benefit analysis (SCBA) under the concept of maqasid Shariah. Second, the study investigates potential of the takaful industry to benefit from the drone-assisted technology and the implications of the potential use of drones in the takaful industry, in the context of Malaysia.

There is a plethora of studies on takaful that discuss on the market behaviour of takaful's participants such as on their satisfaction towards the takaful policies and services 
rendered by the takaful operators (Akhter et al. 2021), intention to purchase and demand of takaful policies (Husin et al. 2016), while on the other end, there are also studies from the perspective of takaful operators especially on their financial performance in the forms of efficiency (Coskun et al. 2021), ratio analysis (Guendouz and Ouassaf 2018) and others (Khan 2019; Ibrahim et al. 2020; Kantakji et al. 2020).

This study differentiates itself by bridging the literature gap to address the issue on the needs for the takaful operators to adopt drone in their operations in view of the potential fulfilment of the maqāșid Shariah and social benefits. Findings from this study can be used when developing policy by the regulators worldwide.

Hence, this study explores the potential adoption of technology by the takaful operators due to the inherent benefits that it can offer; albeit serious implication that needs to be considered will be discussed further in the following section. This paper aims to address these research questions:

i. How the use of drone by takaful operators will be able to contribute to the fulfilment of maquassid of Shariah

ii. Why is the maqușiid based SCBA is essential for the takaful operators in the context of drone usage?

iii. What are the potentials benefits that drone can offer to the takaful operators and the takaful participants?

The paper is organised in the following way. A literature review discusses on the use of drones and their potentials in the takaful industry followed by a theoretical discussion on the maqāsid Shariah and the development of the maqāsid based Social Cost and Benefit Analysis SCBA. The next section discusses the methodology used for this study followed by the findings of the study and the implications they bring. The final part draws a conclusion on the potential use of drones in the takaful industry and the implications that that the takaful operators need to consider.

\section{Literature Review}

\subsection{Current Developments of Takaful}

Recent report by EY (2020) shows that there is significant different in term of penetration rate for insurance and takaful business in the Asia-Pacific region, in which the life insurance or family takaful depicted decreasing trend compared to the general insurance and takaful business which recorded growth. See Table 1.

Table 1. Penetration rate life versus non-life policies (EY 2020).

\begin{tabular}{ccc}
\hline Types of Business & Year 2013 & Year 2018 \\
\hline Life policies & $4 \%$ & $3.8 \%$ \\
Non-life policies & $1.9 \%$ & $2.1 \%$ \\
\hline
\end{tabular}

In the context of takaful operators in Malaysia, relatively the penetration rate is still low but growing in comparison to the conventional insurance. Zainul (2018) describes that the conventional insurance recorded an increase of $5.2 \%$ for life business, while the general business experienced contraction of $1.8 \%$. On the other hand, family and general takaful businesses mushroomed at 7.5\% and 5.9\% respectively. Regional development depicted nearly the same trend. For instance, takaful sector in Indonesia for family and general takaful business recorded gross contribution (premium) received at $10 \%$ and $2 \%$ respectively (Fitch Ratings 2020). One of the main drivers of this phenomenal growth is technology.

The Industrial Revolution 4.0 has pressing companies and governments around the globe to embrace the latest technology and strategies to respond to the sophisticated demands and challenges-takaful operators are not exclusive from this (Manaf and Amiruddin 2019; Saad and Fisol 2019). Likewise, the current situation of Covid-19 pandemic has facilitated the takaful operators to be more adaptive to the takafultech or takaful technology in order to be agile, flexible and responsive towards the customers' needs. 
This is evidenced by the World Insurtech Report 2020 by Capgemini Research Institute cites that takaful and insurance companies are aware on the evolvement of the customers' preferences and technology has connected them which has pave way for more seamless and omnichannel access to reach them (Capgemini Research Institute 2020). Accordingly, technology has enabled takaful operators to recruit more customers and they are riding high based on their performance and the benefits are channelled back to the takaful participants (policyholders) in the form of investment returns and lower premiums.

In addition, claim management is one of the pertinent issues to the takaful operators as well as to the participants because it influences the rate to determine the premium that being charged on the participants and eventually the profitability of the takaful operators (Muhamat et al. 2017). It is imperative to note that takaful operators are entrusted by the takaful participants to manage their takaful certificates or policies by ensuring their financial claims are vetted and disbursed accordingly as per the agreed agreement, and prior to that the takaful participants have to contribute their payment or premiums timely.

The claim process of takaful is similar like conventional insurance that requires several important steps to be followed, started from submission of the claim form and relevant documents such as hospital bills, police report, loss adjuster report, policy or takaful certificate, among others. In general, most of the takaful operators do not provide definite period to disburse the compensation because it is based on case-by-case basis. In other words, if the case is complicated or lack of documentation, the process might be longer. Nevertheless, some takaful operators have specified minimum duration to process the financial claims, for instance within 14 days, yet, it can be longer if the same issues happened (Knaul et al. 2018).

Muhamat et al. (2018) emphasise that the minimum period is still time-consuming especially the underlying motive to take takaful policy is to relieve the financial difficulty of victim or family members in the event of calamity. This is important considering the basic needs like foods and shelter are needed even during the waiting period to process the financial claims-ironically these require money.

The situation can be exacerbated in the event of mass disaster (natural or man-made disaster) because it affects a large number of people (possibly some of them are the takaful participants). Catastrophes such as flood, hurricane and tsunami are examples of natural disasters while man-made disasters are the likes of fire at the residential or industrial areas, collapsed of the building due to lack of quality for the material used and others. Hypothetically, if they (the victims) made financial claims to the takaful operators, it can be postulated that the time taken to process the financial claims will be longer due to the complexity of the incident (mass disaster) and consisting a large number of victims.

Therefore, any delays or longer time taken to process the claims might tarnish the image of takaful operators and industry especially being Islamic financial institutions, they are expected to be seen and act towards assisting the customers (takaful participants) (Muhamat et al. 2017). Thus, an innovative approach must be developed to expedite the claim process (Malaysia Insurance 2018), especially during the mass disaster, irrespective of natural or man-made disasters.

Drone, the "electronic bird" is one of the paraphernalia that is suggested to be adopted by the takaful operators due to the potential benefits that it can bring in the context of pre-and during the claim management process. Nevertheless, the use and acceptance of drone by the takaful operators is low (our initial survey indicates as none) compared to the developed countries.

It is important to note that Malaysia is a country that is not located in the Pacific Ring of Fire, thus, several natural disasters such as earthquake, typhoon and volcanoes are not affecting the country. Nevertheless, the impact of the natural disasters on the neighbouring countries will give some vibration of tremor to Malaysia. In other words, some damages to the properties and human's life are possible. This has happened in 2008 during the tsunami that hit Acheh (Indonesia) which caused some damages to several areas in Peninsular 
Malaysia. Nonetheless, Malaysia faced others natural disasters such as floods (happens every year) and occasionally hurricanes that affect the East Malaysia particularly in Sabah.

In another perspective, takaful operators that are operating in a country that is prone to the natural disaster such as Indonesia, which lies in the Pacific Ring of Fire, really need to consider this issue seriously based on the following discussion.

\subsection{Drone in Insurance}

Drone is termed as unmanned aerial vehicle (UAV) that is manoeuvred by a person (known as pilot) by handling the remote control. The drone can be used for various purposes such as recreational, scientific, agricultural, military and commercial (Terrance et al. 2016).

Terrance et al. (2016) describe that autonomous insurance drone will have sensor device customized to gather the insurance related data which is then disseminated to the insurance processor through a wireless communication device. Kim and Davidson (2018) suggest that drone has been used in humanitarian and post-disaster relief initiatives with high success rate. Thus, if the drone is utilized in the insurance sector then it will be able to innovative and transform the sector which is perceived as "money taker; less giver". The use of drone in insurance sector is not a totally new practice for some countries like the USA, the UK and other developed countries, but for Malaysia it is something that has not been practiced before as per the preliminary research that has been conducted by this study. The same situation also occurs to other mature takaful markets in the world such as in Indonesia and the Middle East countries.

Importantly, the experiences from developed countries with regard to the adoption of drone showed that drone is possible to assess for injury inspection, compliance with an insurance policy conditions, property damage inspection and fraud investigation (Reuters 2017). These features assisted the insurance companies or possibly the takaful operators (if they adopt in the future) by achieving the common objective to facilitate and expedite claim inspection as precise as possible and to avoid fraud cases when making claims (Shmat 2018).

\subsection{Maqāṣid Shariah in Relation to the Use of Drone}

Lewis and Algaoud (2018) describe Shariah as literally means "the way to the source of life" and technically a legal system to be adhered. There are two sources of Shariah, primary sources in forms of Al-Quran and sunnah (the deeds of Prophet Muhammad S.A.W) and secondary sources in forms of ijma (consensus of opinions among the Shariah scholars) and qiyas (logical reasoning deduced by the Shariah scholars in comparison with the situation as per fatwa that has been issue in the past). Shariah serves as the body of Islamic law for every transaction that happened in Muslims' daily activities.

The Shariah has five objectives to be achieved which are to protect religion, life, progeny, intellectual and property which commonly referred as maqāsid of Shariah. Auda (2008, p. 6) refers to the al-Qarafi's statement that reflects the basis of maqāsid of Shariah:

"A purpose (maqsid) is not valid unless it leads to the fulfilment of some good (maslahah) or the avoidance of some mischief (mafsadah)".

The basics criteria of maqāșid Shariah are segregated into three levels started by daruriyyat (necessities), hajjiyat (complementary) and tahsiniyat (embellishment). These become the yardstick to categorize whether a particular issue is critically needed or otherwise. Auda (2008) has discussed on the evolvement of maqāșid Shariah over time from emphasising on the individual to be more collective. This is an important aspect that needs to be considered and highlighted on the manner of the Islamic scholars viewed society's needs over the individual's; but still within the scope of justice and fairness as intended in the primary sources of Shariah-the Quran and sunnah.

The Quran (2:188) mentions: 
"Do not eat up one another's property among yourselves by false means (unjustly) nor give bribery to the judges so that you may knowingly eat up a part of the property of others sinfully".

Thus, Shariah scholars emphasised that while maqāsid Shariah is intended to protect the five categories as mentioned earlier, it should not transgress the rights of others.

Likewise, total dependence on the existing conventional framework may not be able to lead decision makers to choose the best technology intervention in light of the Shariah (Islamic law). There are several issues regarding the conventional framework that need reconsideration from the Islamic standpoint. Moreover, the conventional framework has been developed over the years without taking into consideration the Islamic input. Decision makers in an Islamic framework should be guided by Islamic values in carrying out their judgments (Jalil 2006).

Maqāșid al-Shariah (objectives of Shariah) has been the central concept in Islam. According to al-Ghazali, "the ultimate objective of Shariah is to promote the wellbeing of the people" (Dusuki and Abdullah 2007). Thus, maslahah (public interest) is the preservation of the objectives of Shariah. From Islamic perspective, dead bodies must be identified quickly to verify the identity of the victim because burial should take place at the earliest possible opportunity and with appropriate burial procedure (Penuel et al. 2013). For example, the employees of an Islamic social welfare organization in Bangladesh have been trained to identify and manage dead bodies. The training emphasized the importance of correct identification procedures so that families may be informed and are able to proceed with proper burial (ICRS 2012).

Islam as a complete way of life has illustrated the ethics and ways to manage the dead bodies. Human beings are given an upmost position in the eyes of God so that even at the time of death, one should be given a respectful ending to this world in the form of a proper burial unless a mass disaster in the scale of what has happened for example in Acheh 2014 where the issue of proper individual burial was beyond question. Identification of the dead in terms of their religious faith is considered important in order to properly accord the methods of burial required by the religious rituals of the believers.

As Islam respects freedom of religion, the Islamic perspective would also consider the rights of a person to be accorded the kind of religious rites for the funeral of the dead. Thus victim identification of the dead is to enable this right of a human being to be upheld. According to Al-Bukhari and Muslim, even the Prophet stands up for the funeral of a Jew, showing his respect to the dead regardless of their religion as Islam is a religion of peace and respect (Elias 2011). However, there are very limited discussions on the importance of quick and efficient disaster victim identification in light of the maqāsid Shariah and maslahah. Thus, this study aims to embark on this path by identifying and measuring the costs and benefits of using drones in disaster victim identification from the perspective of maqāșid Shariah and maslahah.

\subsection{Social Cost Benefit Analysis (SCBA)}

Cost Effectiveness Analysis (CEA) has been widely used to evaluate the cost and effects of specific newly proposed intervention as compared to the current existing practice. This analysis is synonymous with health economic evaluation (Marsh et al. 2012). The National Institute for Health and Clinical Excellence (NICE) defined CEA as an economic study design in which consequences of different interventions are measured using a single outcome, usually in 'natural' units (for example, life-years gained, deaths avoided, heart attacks avoided or cases detected). Alternative interventions are then compared in terms of cost per unit of effectiveness (NICE 2013).

In contrast, Cost Benefit Analysis (CBA) framework surveys all the impacts caused by a project or other policy measure. It comprises both the financial effects and all the societal effects. The main aim of CBA is to attach a price to as many effects as possible in order to uniformly weigh the various effects associated with the proposed project. As a result, these prices reflect the value a society attaches to the caused effects, enabling the decision 
maker to form an opinion about the net social welfare effects of a project (Decisio Economic Consulting 2018).

On the other hand, a Social Cost Benefit Analysis (SCBA) at its most basic is a Cost Benefit Analysis (CBA) that takes into account all the social impacts of decisions on people that CBA did not consider. SCBA considers all the intangible social benefits and impacts of a project on people and converts it into monetary value.

Brent (2006) signifies that social cost benefit analysis is a concern to the government when formulating new policy because the government needs to strike a balance between the benefits of subsidizing and the costs involved, which must bring benefits to the society. For projects that have great societal impact, it is useful to evaluate all costs and benefits including the less tangible social costs and benefits. Even if initial costs are high, the potential for equally high social benefits may justify interventions to adopt high initial costs new technology. However, if the industry is reluctant to adopt this new technology in view of the high initial costs, and the possibility to recoup from such investments is risky, who then should bear this extra costs?

The Treasury of New Zealand (2015) emphasises that before measuring the benefits and costs; it is important to identify the people who will be affected and whose costs and benefits that must be considered as a result of the decision. On the other spectrum is the private benefit that is specifically experienced by the producer or customer of a particular product after offsetting the private cost which is associated with the service or product (Lee 2020). Interestingly, the social benefit encompasses private benefits together with benefit to the third party as externality effect—-the positive spill over (Asian Development Bank 2013; Lee 2020).

In the context of private sector on SCBA, the Asian Development Bank (2013) report has emphasised clearly the role of government to intervene especially if the intervention has the possibility to improve the society's condition. Commonly, it would be difficult to have the net positive results (sometimes they are non-gainers); and always the aggregate benefits will be the reference or motivation to adopt or execute a particular strategy.

In the context of this study, the attention is on the private sector characterized by the takaful operators whether to adopt drone as part of their business operations or otherwise. For private sector like takaful operators, the consideration is different due to the presence of shareholders as the principal and the takaful operators are the agents as exemplified in the agency theory (Muhamat et al. 2019). Nevertheless, the situation for takaful operators is unique because there are two principals in the business operations; which are the shareholders and takaful participants. Likewise, this conundrum needs further evaluation to determine who is the principal's principal in takaful operators' operations and the raison d'être with regard to the existence of takaful operators (Archer et al. 2009; Rubio-Misas 2020).

Figure 1 depicts the overall landscape of this research project which this study has emphasised earlier that for this paper, it will present the preliminary findings on one of the research project's objectives, which is to explore on the potential adoption of drone which is postulated to influence the takaful operators from the SCBA's perspective within the maqāșid based framework. The ultimate aims are to emphasises on the reduction and elimination of the harmful elements, and at the same time promoting and increasing the social benefits.

The potential adoption of drone by the takaful operators must be evaluated beyond the conventional accounting lens by incorporating the social benefit impacts which are espoused as well by the maqāṣid Shariah. In addition, in the context of mass disaster, drone will bring significant assistance to the main stakeholders during the emergency period: family; takaful operator; rescue team (first responder); and government. A customised drone for disaster victim identification (DVI) has the ability to trace and identify the victim quicker compared to the conventional rescuing process that relies heavily on human's physical (to get into the disaster area to rescuing and identifying the victims). 


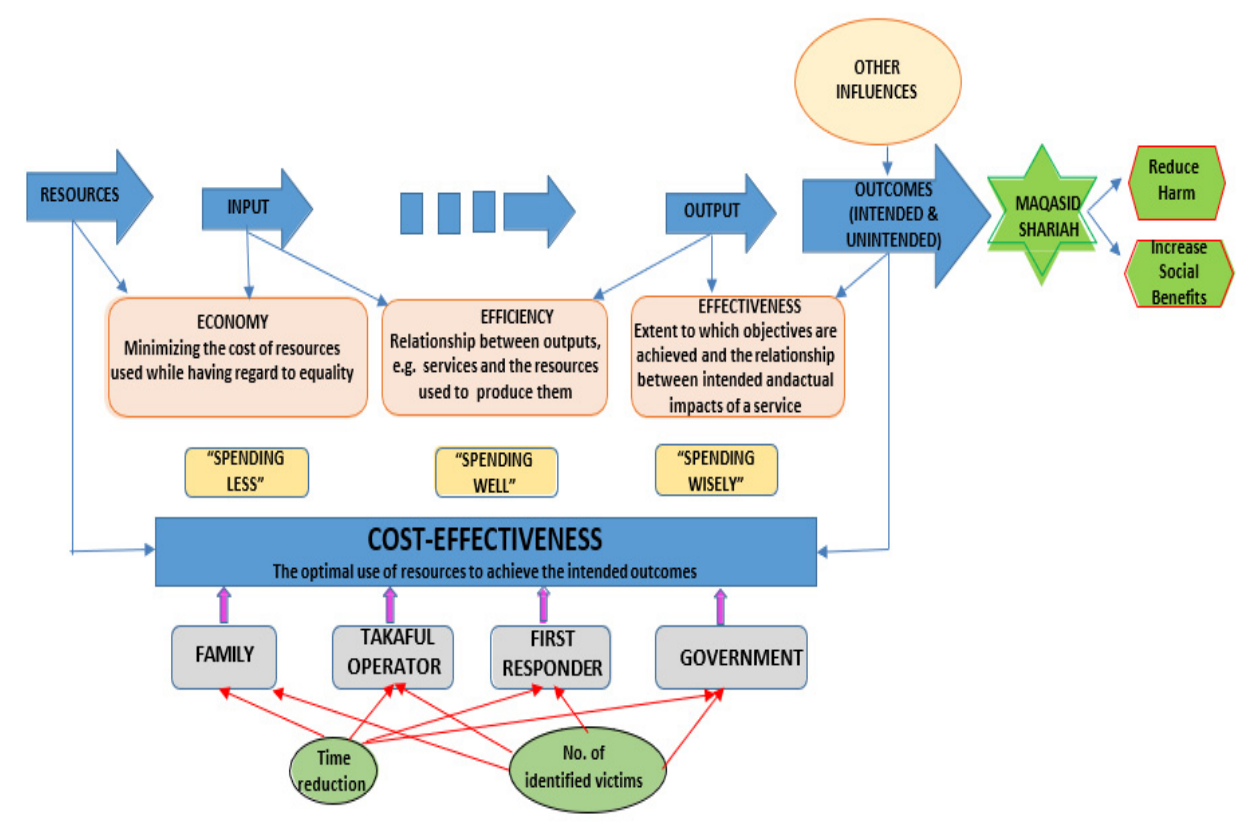

Figure 1. Diagram 1: Social cost benefit analysis (SCBA) framework on drone adoption (C) This framework has been submitted to the Intellectual Property Corporation of Malaysia (MyIPO) Copyright reserved (c) Universiti Teknologi Mara 2021.

Thus, when the victims can be identified faster, this will expedite other important tasks such as burial, compensation for the victims (either death, injury or damages to the property or combination of them). Likewise, when the burial process can be done immediately as urged in Islam, it will pacify emotion of the victim's family and permit the next of kin to submit for financial claims to the takaful operator for compensation so that the financial claim can be processed at once and disbursed immediately to help the family members. In the context of government, if the victims' condition can be reinstated as good as before the calamity occurs, that has assisted the government in performing one of its roles to the citizens. It is important to note that, this situation varies and the approach also might be different due to the nature of the coverage whether it is under family or general takaful business. Nevertheless, the essential element is to facilitate the immediate assistance-drone seems make this possible.

\subsection{Takaful Concepts}

Takaful is a mutual protection insurance scheme which all participants agree to compensate (assist each other) in the event of calamity as prescribed in the takaful certificate or policy. The business operation of takaful operators can be either mutual form or stock form takaful (Gönülal 2012). The main difference is that for mutual form takaful the participants themselves manage the business operation or they hire specific staff to manage the business on their behalf. In contrast, the stock form takaful has shareholders' presence to manage the business operations and shouldering together some of the risks especially the operational and investment (limited to shareholders' fund only). Nevertheless, either mutual form or stock form takaful - takaful participants are one of the principals in stock form takaful while the sole principals in mutual form takaful.

The discussion above foreshadowing that takaful participants are the intended beneficiaries in takaful operation as well as they occupied the pinnacle position of the principal's principal in term of principal-agent relationship between takaful operators and the takaful participants. Furthermore, to put it into perspective, the raison d'être of takaful operators is to manage the takaful participants' policies and compensation and the role of shareholders exist here by providing the paid-up capital to setting-up the company or takaful operator for this purpose. In return, the shareholders will reap the benefits from the business in form of investment profit and wakalah (agency fee). Thus, without neglecting the role of 
shareholders in takaful operation; the takaful participants are having the upper-hand in the tripartite relationship of takaful operators-shareholders-takaful participants.

The arguments above have positioned takaful operators as private companies but laden with social responsibilities toward the takaful participants based on the premise that they are: the principal's principal; and also the beneficiaries. Thus, the onus is on the takaful operators to explore the SCBA particularly on the adoption of drone in their operations. Table 2 summarizes the key discussions of the literature review section.

Table 2. Summary of key discussions in the literature review section.

\begin{tabular}{|c|c|c|}
\hline & $\begin{array}{l}\text { Contribution from the } \\
\text { Previous Literature }\end{array}$ & Contribution from This Study \\
\hline $\begin{array}{l}\text { The use of drone in } \\
\text { insurance and takaful } \\
\text { sector }\end{array}$ & $\begin{array}{l}\text { Previous literature signifies } \\
\text { the use of drone by insurance } \\
\text { companies in the developed } \\
\text { countries to assess damages } \\
\text { and even pre-underwriting } \\
\text { process to determine the risks } \\
\text { before confirming the } \\
\text { premium. }\end{array}$ & $\begin{array}{l}\text { This study indicates that the use of } \\
\text { drone by the takaful operators in } \\
\text { negligible, almost nil. Thus, it raises } \\
\text { potential area to be investigated } \\
\text { further. }\end{array}$ \\
\hline The impact of takafultech & $\begin{array}{l}\text { The IR } 4.0 \text { has pushed the } \\
\text { takaful operators to embrace } \\
\text { the technology faster; but } \\
\text { such improvements are in the } \\
\text { areas of sales and marketing, } \\
\text { and customer service. }\end{array}$ & $\begin{array}{l}\text { The takafultech should impart on } \\
\text { the other business functions such as } \\
\text { underwriting and the claim } \\
\text { management process because these } \\
\text { are the critical areas that are } \\
\text { exposed to manipulation, fraud and } \\
\text { tardiness which can be improved } \\
\text { with the adoption of drone. }\end{array}$ \\
\hline Maqāṣid Shariah & $\begin{array}{l}\text { Previous literature has } \\
\text { established the importance of } \\
\text { takaful according to the } \\
\text { maqāṣid Shariah. }\end{array}$ & $\begin{array}{l}\text { This study has depicted that the } \\
\text { fulfilment of the maqassid Shariah } \\
\text { can be further strengthened by } \\
\text { adopting drone in the takaful } \\
\text { operation due to the inherent } \\
\text { benefits that the technology } \\
\text { possesses. }\end{array}$ \\
\hline $\begin{array}{l}\text { Social cost benefit } \\
\text { analysis (SCBA) }\end{array}$ & $\begin{array}{l}\text { SCBA is commonly used by } \\
\text { the government agencies to } \\
\text { consider and evaluate the } \\
\text { right project that they should } \\
\text { implement over the other. On } \\
\text { the other hand, this tool is } \\
\text { rarely used by the private } \\
\text { companies. }\end{array}$ & $\begin{array}{l}\text { SCBA is the appropriate tool to } \\
\text { assess on the potential adoption of } \\
\text { drone and the benefits that it brings } \\
\text { to the takaful operators, takaful } \\
\text { participants and community at } \\
\text { large. Thus, relative comparison of } \\
\text { cost to other benefits that will be } \\
\text { received by the society need to be } \\
\text { established. Takaful operators need } \\
\text { to analyse the SCBA to reflect their } \\
\text { role as the value-based financial } \\
\text { intermediaries and Islamic financial } \\
\text { institutions. }\end{array}$ \\
\hline
\end{tabular}

\section{Method}

This study presents an excerpt from a bigger research project under the Transdisciplinary Research Grant Scheme (TRGS) on the impacts of drone for disaster victim identification. However, for this paper, discussion is focused on how the framework of maqussid Shariah can be used to develop a new framework of the social cost benefit analysis (SCBA).

This study adopts qualitative method as suggested by Merriam and Grenier (2016) and Yin (2018), specifically case study to explore on this rarely discussed issue. Thus, this study used semi-structured interview sessions with the key informants who are: Islamic 
finance and Shariah expert (he is one of the members of the Shariah Advisory Council (SAC) of the Central Bank of Malaysia); professional accountant who is also an expert on SCBA; and last but not least, a drone practitioner who also owns a drone services company.

The interview questions were developed prior to the interview session and validated by the experts who have Shariah and accounting qualifications. Research protocol for this study is established and mapped to the study's objective so that the necessary steps are followed to avoid mistake and to ensure ethical conduct is followed. Hence, it will increase the validity and reliability of the interview questions, which helps to achive the study's objective as advised by Merriam and Tisdell (2016) and Bryman (2016). The interview discussions probed themes based on the use of drone, maqūșid Shariah and social cost benefit analysis. The transcribed data were analysed by using thematic analysis, an approach for identifying, analysing and reporting patterns or themes. As it was conducted during the COVID-19 pandemic, the interview sessions were organized via online platform, using Google Meet.

Saturation point is the critical element in qualitative study to determine the number of key informant for sufficient or attainment level for data collection. This is due to the rule that a single key informant can be sufficient for a study if the "richness" of data or information able to meet the research objective (Merriam and Tisdell 2016). Nevertheless, many qualitative gurus have shared their perspectives on this which can be concluded that; the saturation point will be closely related to the research objective and depending on the purpose of the study either consultation, PhD or research grant (Blaikie and Priest 2019; Guest et al. 2006). In other words, for consultation project and research grant which are subjected to the specific duration to complete the research, the number of key informants can be lesser compared to PhD research, which the latter is expected to prove the robustness of the study with minimum 15 key informants to correlate with the long duration of $\mathrm{PhD}$ research.

Likewise, this study is part of the bigger research project, the Transdisciplinary Research Grant Scheme (TRGS) which focuses on the impacts of drone for disaster victim identification. Thus, the number of key informants are actually more than three. The initial key informants also involved loss adjuster, actuarial expert from takaful operator, senior managers from the central bank, first responder (for disaster relief team), representatives from the Malaysian Takaful Association (MTA) and director from the National Disaster Management Agency (NADMA).

However, this paper only focuses on the three key informants to provide the preliminary findings specifically on the SCBA in the maqāsid Shariah based framework facilitated by the potential use of drone by the takaful operators.

\section{Findings \& Discussion}

The findings were gathered from the key informants' feedback toward statements with regard to the issue on the connection between SCBA and maqāsid Shariah on the potential adoption of drone by the takaful operators in their operations.

\section{i. $\quad$ Key informant 1-Drone practitioner perspective}

The first key informant who is a drone expert and practitioner (he owns a drone consultation) has related his experiences on the potential benefits that drone can bring to the takaful operators if they use drone to assess damages. The benefits are in terms of cost reductions, accuracy when determine the damages, mitigation of fraud, preliminary assessment of damages (during the underwriting process) and expedite compensation process.

Drones can also be used to discover when a property does not have a feature that the owner claims it does.

Insurance fraud is a common problem in insurance and takaful sectors and mitigating the fraud can help company to save significant amount of money. Drone can assist in 
this situation by assessing the damages as accurate as possible before the compensation being determined.

Drone can be used to capture images of the insured properties prior to the submission of proposal form so that the takaful operators can minimize the fraud attempts.

Drone can potentially transform the way the insurance companies or takaful operators mitigate their own risk. Moreover, they also affect how quickly companies respond to the problems when disaster hits which should be followed by the prompt damage evaluation and identification and timely compensation distribution.

These benefits are consistent with previous literature and experience of other drone companies in other countries.

ii. Key informant 2-Shariah expert perspective

The Shariah expert has clarified as such:

The first intention of maqāsid which is general in term of scope is defined as the purpose and wisdom behind the enactment of all or most of the Shariah rulings. The specific definition is best illustrated by Ibn Ashur since the code of conducts from Allah is to achieve specific benefits or to preserve their prime interests in their daily activities so that their individual interests would not eliminate their general interests as a result of negligence or individual whims and desires.

He emphasised that the maqāșid Shariah as intended in Islam is to ensure the rights that beget benefits for a Muslim is protected and the social interests are having priority over the private interests. This is concurred by Azis et al. (2020); Hudaefi and Noordin (2019) and Auda (2008) on the purpose of the maqāṣid of Shariah.

The objectives of Shariah are divided into daruriyyat (necessity), hajiyyat (complementary) and tahsiniyyat (embellishment).

This is the stage of priority being determined in Islam according to the hierarchical order from the daruriyyat or necessity, to complementary or hajiyyat and tahsiniyyat or embellishment (Siddiqi et al. 2019). Necessity is a must and without it a person cannot live such as foods, shelter and safety. The next level is complementary that elevates the condition of a person to a higher level which makes the person to be more convenient. Lastly is the embellishment, which is luxury products or services. This can lead to extravagant and wasteful which is strongly condemned in Islam because Islam views properties as trust that Muslims as the trustees must manage them wisely so that the benefits of the properties can be enjoyed by as many people as possible (Mansour et al. 2015).

Therefore, in the context of adopting drone by the takaful operators, it is important to assess the category whether it is a necessity, complementary or embellishment. Truly, this is not an issue that can be discerned and confirmed without in-depth study.

Nevertheless, the Shariah expert has provided insights on the potential benefits of drone for the takaful operators that cover pre-disaster or accident, which is actually to be used when identifying the potential risks of the property. The information gathered by the drone can potentially enhanced the data that the takaful operators have which possibly influenced the underwriting risks that will be documented and reflected as premium or contribution that the policyholder needs to pay. Likewise, to have sensible amount that is charged for the takaful certificate is protecting the interests of both parties (takaful operators and takaful participants) in a way that takaful participant will not be charged for risks that are not associated with the property and for the takaful operators in the context that the amount charged correlates with risks that are inherent from the property.

The use of drone can be seen as not only for claims purposes to assess the damages to determine the compensation. Also, drone can be used to determine the cost of underwriting for the policy.

For instance, if there are damages and the financial claim is RM 1 million based on the current method. However, when using drone and perhaps due to its accuracy, the 
compensation for the same damages is lesser than RM 1 million, such as RM 6 million or RM 7 million. This is a huge reduction and savings.

He further described that maqūṣid Shariah emphasised on the avoidance and elimination of the potential dangerous event which he connected this to the takaful operators that the social benefit analysis must cover as many elements as possible in order to formulate or determine the costs associated with drone and the benefits that drone potentially brings. Thus, this will assist the relevant stakeholders particularly the takaful operators, regulators and consumer association or NGOs to have serious discourse on this issue especially if the benefits outweigh the costs (Auda 2008; Lee 2020).

Maqāsid Shariah stated clearly that harm shall neither be inflicted nor reciprocated. In my opinion, the aim of a social benefit analysis is to attach a price to as many effects as possible in order to uniformly weigh all the impact that may be caused by external factors (examples are pollution, safety, indirect (labor) market, legal aspects and others). As a result, the prices will reflect the value a society attaches to the caused effects, enabling the decision maker to form a statement about the net social welfare effects of a project.

iii. Key informant 3-Certified accountant and social cost benefit analysis (SCBA) expert perspective

The last key informant who is an expert in social cost benefit analysis (SCBA) and certified accountant discussed on the issue of SCBA and the utilization of drone especially in the context of mass disaster or calamity. While drone can be used to assess damages either for individual case or aggregate cases after disaster occurs. It is important to highlight here that disaster can be in the form of natural or man-made disaster.

The former is unanimously considered as "act of God" or scientifically as earth's natural phenomenon like hurricane, typhoon, tsunami, earthquake and others, while the latter concerned on the calamity which is happened due to morale hazard (Bos et al. 1974). The morale hazard in the context of man-made disaster such as insensitive toward fire precaution steps (that caused fire to entire apartment), below quality material used when constructing building that caused the building to collapse and others (Chan 2015). It is hard to confirm which disaster is worse because disaster normally associated with loss of life and damages to the properties. Nevertheless, the man-made disaster can still be prevented compared to the natural disaster that can happen at any time.

Natural disasters such as hurricanes and earthquakes to common but still dangerous calamity like droughts and floods are affecting the human lives as well as economic activities of the businesses, individual and government-economic losses.

The disaster will affect the victim as well as the government and takaful operator or insurance company in term of compensation (from takaful operator) and assistance (financial or in-kind from the government) to be issued to reinstate the position of the victim as before the disaster occurs. The government's coffer will be used (from the tax payers' money) while for the victim, if it is a business then it will be having operation disruption while if the victim is an individual who was injured or killed during the calamity, the family's financial situation will be affected.

Therefore, in this situation, assistance and compensation should be rendered as soon as possible because emotion of the victim and families or employees are at stake-drone is postulated to be able to bridge the gap due to its distinguished features and benefit.

When disaster occurs the property owner will have to bear the losses but the public also will be affected accordingly because the impact from disaster (depends on the magnitude) in most cases will cause damages to public properties as well such as road, electricity cables etc. Therefore, the local or federal funds will be used to rebuild the facilities as well as the insurance or takaful operators to distribute compensation if the victim has houseowner or householder policy.

However, does it commensurate between costs and benefits? The key informant explained further on this by emphasizing on the concept of SCBA and emphasised that 
government must consider the adoption of drone by the takaful operators (as recommendation or regulation to the sector) if the basis between costs and benefits can be assessed and measured. Likewise, the Malaysian government is suggested to get feedback and learn from other countries particular on the use drone so that more and updated information can be derived before the Malaysian government can form opinion on this initiative.

Social benefit is the total benefit to society in terms of producing or consuming the goods or services by emphasising on the private benefits as well as external benefits gained from production or consumption of the particular services or goods. Likewise, the social benefit can be deemed as having the upper hand over the private benefit if the goods or services have significant external benefit, in other words the social benefit is more than the private benefit.

The benefit received by the victims and government must be considered as social benefit if it is being considered by many governments in other countries as their main goal; having capacity to improve the outcome relative to the costs to achieve them; replaces the traditional or current method that is costly and lacking in term of quality; the responsibility of the government to identify the suitable approach and will be held accountable for the outcome; and if it improves and increases the "value for money".

In addition, the takaful operators should not being forced to adopt drone because takaful operators are technically agents for the takaful participants. Therefore, every decision they made, they should carefully consider the impact on every takaful participants who are their principals. Interestingly, the idea to adopt or use of drone is actually to ensure the benefits of the takaful participants are preserved. The key informant suggested that while conventionally, government and even firm is focusing on the compliance activities or monetary return for every money that is spent which is considered as backward-looking but emphasise on value improvement is deemed as forward-looking which can bring transformation to the sector.

However, most governments in the world focusing more on the checklists and measuring compliance with evidence-based assessment rather than achieving better outcomes. While undeniably compliance activities are important; but it is backward-looking exercise and therefore I feel it as inadequate. The imporant aspect that needs to be emphasised more is the value improvement which is a forward-looking process and drives toward transformation.

The discussion by the SCBA expert seems pressing on the government to lead the initiative. This is not an anomaly because SCBA is more relevant for the government instead of private companies like takaful operators. Nevertheless, as being argued and discussed previously, the takaful operators as well as regulators must assess this issue because conceptually the use of drone compatible with Shariah precepts and the SCBA requirements as well as brings greater benefits to the takaful participants who are not only the principals in the takaful business operations but also the ultimate beneficiaries.

The major concern in social cost benefit analysis is to have as many as costs as possible and to compare them against the heterogeneous effects so that the value which will be the consideration or outcome from this process will be able to reflect the costs that the decision maker whether government or company to consider on the social welfare effects from adopting or implementing new method or approach.

Likewise, empirical study on this issue is needed so that it can substantiate the assertions on the use of drone particularly in terms of SCBA. An empirical study can also assess the direct effects and the indirect effects that are associated with the use of drone in the context of takaful operations. The findings will be useful to confirm support or negate the SCBA aspect of drone which will assist on better decision-making process.

The key informant has succinctly clarified the costing elements that need to be measured for SCBA: 
Three elements must be considered which are direct effects, indirect effects and external effects from a particular project or exercise that is considered to be implemented. The direct effects can be best linked to the costs and benefits that connect straight away to the owners or users of the properties or project while the indirect effects are the costs and benefits that are experienced by others outside the "circle" of the project or properties. On the other end, the external effects are the costs and benefits that are more universal and affect others such as environment, safety and nature (biodiversity).

The social issues should have been given the same treatment in terms of the use of unquantified data over quantified data because social issues in most cases are dynamic and hard to be assessed with numerical process. Likewise, the integration of cost-benefit is needed and relevant matrix that can be treated as important component like the financial impact and this can possibly achieve by having diverse stakeholders to look at the particular issue.

\section{Conclusions}

This paper reports a preliminary study based on the qualitative expert opinion on the feasibility adoption of drones by the takaful operators. We also explore the idea of how the SCBA which is premised on the importance of social costs and social benefits to any assessment on the cost effectiveness as opposed to the usual practice in the conventional cost accounting which measures private costs and benefits only.

This will be particularly useful for projects with wide social benefits despite high initial costs, and such interventions could be justified on the basis of the huge social benefits which represent an improvement to the general welfare of society or the affected community. The paper also discusses how the SCBA can be further improved facilitated by the adoption of drone, in the context of new dimensions of social costs and benefits by taking inputs from the maqāșid Shariah framework. In other words, this study proposes to the takaful industry a concept of measuring cost effectiveness which broadened the financial perspective to incorporate externalities to the third parties and the wider public. This is certainly in line with the maqașid Shariah which the Islamic finance industry is premised.

While drones have been used in Malaysia in various industries, the findings from this study confirms that the takaful industry has yet to adopt the use of this new technology. The study also establishes the feasibility and huge potential on the use of drones to enhance the efficiency of the takaful industry based on its benefits to the stakeholders. Thus, this study suggests that takaful operators in Malaysia and in other mature takaful markets should consider seriously the adoption of drone technology in their takaful business operations. We have established in this study; based on the experts' opinions on the positive impacts that can be derived during the pre-underwriting process as well as during the claim (damage assessment) process. Amongst the main benefits are in terms of accuracy and precision when determining the underwriting costs, a fast and efficient claim management process and reduction of the potential fraud for the entire process.

This study opines that in order to reduce the initial high cost of the drone technology, it is not necessary that each takaful operator establishes its own drone unit, instead cost sharing could be established using a collaborative effort by the industry through initiatives that can be led by the industry's association. Hence, associated costs can be borne together by the takaful operators through the association such as Malaysian Takaful Association (MTA), the Indonesian Shariah Insurance Association (AASI) or to other countries that have matured takaful markets such as countries in the Gulf Cooperation Council (GCC).

Drone has been adopted by many conventional insurance companies in the developed countries, therefore the takaful industry has already have the global benchmarking. In case of mass disaster, the national level disaster management agencies such as NADMA in Malaysia should provide the drone services and the relevant data from the drone technology could be provided for the takaful operators at minimal costs.

Nevertheless, the takaful operators cannot be enforced to adopt drone in their operations due to the costs that surely will hit the companies' balance sheet. This is the 
main consideration of the shareholders who are also the principals in the takaful business operations. To reiterate, collaborative effort by the industry through the association can be the feasible alternative to adopt drone in the takaful operations.

In term of limitation, as mentioned earlier, this study is part of a bigger research project and this paper only discusses one perspective from the main research project. Nevertheless, this study has been able to provide preliminary insights into one of the emerging issues in takaful which is rarely being discussed. Like any other research during this Covid-19 pandemic, it has been delayed tremendously. Yet, these preliminary findings should be able to contribute toward the literature in this area and reference when formulating policy for the industry.

Last but not least, for future research, this study suggests that a cross-country comparison on the potential adoption of drone by the takaful operators will pave way for better understanding on this issue from a global perspective. This is essential because country's geographical location has the potential to influence the urgency of the takaful operators to adopt drone in their operations. For instance, countries that are prone to natural disasters such as earthquake, forest fires, hurricanes and others, are postulated to have higher tendency to adopt drone to facilitate the damages and claims processes, as shown by the insurers in the United States of America.

Author Contributions: Conceptualization, A.A.M., S.S. and S.M.; Formal analysis, S.S.; Investigation, A.F.Z. and G.S.; Writing—original draft, A.A.M. and A.F.Z.; Writing—review \& editing, A.A.M. All authors have read and agreed to the published version of the manuscript.

Funding: This research was funded by Ministry of Higher Education Malaysia, grant number 600-IRMI/TRGS 5/3 (001/2019)-3 and The APC was funded by the same research grant.

Institutional Review Board Statement: The study was conducted according to the guidelines of the Declaration of Helsinki and approved by the Research Ethics Committee of UiTM, protocol code REC/08/2021 (MR/694).

Informed Consent Statement: Informed consent was obtained from all subjects involved in the study.

Acknowledgments: We would like to express our gratitude to the Ministry of Higher Education Malaysia for the Transdisciplinary Research Grant Scheme (TRGS), file no. 600-IRMI/TRGS 5/3 (001/2019)-3 that was awarded to us. The research grant has assisted us in conducting this project.

Conflicts of Interest: The authors declare no conflict of interest.

\section{References}

Akhter, Waheed, Hassan Jamil, and Kim-Shyan Fam. 2021. Islamic influence on customer satisfaction: Evidence from takaful and conventional insurance industry. Journal of Islamic Accounting and Business Research 12: 524-43. [CrossRef]

Archer, Simon, Rifaat Ahmed Abdel Karim, and Volker Nienhaus. 2009. Corporate governance and stakeholder rights in Islamic insurance. In Takaful Islamic Insurance: Concepts and Regulatory Issues. Singapore: John Wiley Sons (Asia).

Asian Development Bank. 2013. Cost-Benefit Analysis for Development: A Practical Guide. Philippines: Asian Development Bank.

Auda, Jasser. 2008. Maqasid al-Shariah As Philosophy of Islamic Law. Herndon: The International Institute of Islamic Thought (IIIT).

Azis, Nur Kamaliah, Marziana Madah Marzuki, and Wan Zurina Nik Abdul Majid. 2020. Fraud prevention in Malaysia: Maqāṣid al-Shariah perspective. Global Business and Management Research 12: 104-16.

Blaikie, Norman, and Jan Priest. 2019. Designing Social Research: The Logic of Anticipation. Hoboken: John Wiley \& Sons.

Bos, Hendricus Cornelius, Martin Sanders, and Carlo Secchi. 1974. Principles of Social Cost-Benefit Analysis Private Foreign Investment in Developing Countries. New York: Springer.

Brent, Robert J. 2006. Applied Cost-Benefit Analysis. Cheltenham: Edward Elgar Publishing.

Bryman, Alan. 2016. Social Research Methods. Oxford: Oxford University Press.

Capgemini Research Institute. 2020. World Insurtech Report 2020. Available online: www.worldinsurtechreport.com (accessed on 5 May 2021).

Center for Excellence in Disaster Management \& Humanitarian Assistance. 2016. Malaysia Disaster Management Reference Hand book. Ford Island: Center for Excellence in Disaster Management \& Humanitarian Assistance.

Chan, Ngai Weng. 2015. Impacts of disasters and disaster risk management in Malaysia: The case of floods. In Resilience and Recovery in Asian Disasters. New York: Springer, pp. 239-65. 
Coskun, Ali, Houshang Habibniya, and Yavuz Keceli. 2021. An efficiency analysis of takaful insurance industry: A comparative study. The Journal of Asian Finance, Economics and Business 8: 111-20.

Decisio Economic Consulting. 2018. Decisio Leading Consultancy firm in Social Cost Benefit Analyses (SCBAs). From Economic Consulting-Decisio Economic Consulting. Available online: http:/ / decisio.nl/en/research/social-cost-benefit-analysis/ (accessed on 21 February 2018).

Dusuki, Asyraf Wajdi, and Nurdianawati Irwani Abdullah. 2007. Maqasid al-Shariah, Maslahah, and Corporate Social Responsibility. The American Journal of Islamic Social Sciences 24: 25-45. [CrossRef]

Elias, Abu Emina. 2011. Hadith on Respect: The Prophet Stands Up for the Funeral of a Jew Out of Respect. Available online: https:/ /abuaminaelias.com/dailyhadithonline/2011/03/30/the-prophet-stood-up-for-the-funeral-of-a-jew-out-of-respectfor-his-humanity/ (accessed on 26 February 2018).

EY. 2020. Asia-Pacific Insurance Outlook: Driving Innovation and Transformation to Seize Opportunities and Sustain Growth. Available online: https://assets.ey.com/content/dam/ey-sites/ey-com/en_gl/topics/insurance/insurance-outlook-pdfs/eyglobal-insurance-outlook-asia-pacific.pdf (accessed on 18 August 2021).

Fitch Ratings. 2020. Indonesia Takaful Dashboard: 2020. Available online: https://www.fitchratings.com/research/insurance/ indonesia-takaful-dashboard-2020-26-02-2020 (accessed on 2 February 2021).

George, Jaevon. 2016. Law Enforcement Use of Drones (Aerial Surveillance). Available online: https://www.linkedin.com/pulse/lawenforcement-use-drones-aerial-surveillance-jaevon (accessed on 15 February 2018).

Gönülal, Serap Oguz. 2012. Takaful and Mutual Insurance: Alternative Approaches to Managing Risks. Washington, DC: The World Bank.

Guendouz, Abdelkrim Ahmed, and Saidi Ouassaf. 2018. Determinants of Saudi takaful insurance companies profitability. Academy of Accounting and Financial Studies Journal 22: 1-24.

Guest, Greg, Arwen Bunce, and Laura Johnson. 2006. How many interviews are enough? An experiment with data saturation and variability. Field Methods 18: 59-82. [CrossRef]

HAKAM. 2015. Putrajaya Announces New Agency to Deal with Disasters. From HAKAM-National Human Rights Society. Available online: http:/ / hakam.org.my/wp/index.php/tag/national-disaster-management-agency-nadma/ (accessed on 13 February 2018).

Hudaefi, Fahmi Ali, and Kamaruzaman Noordin. 2019. Harmonizing and constructing an integrated maqāṣid al-Sharīah index for measuring the performance of Islamic banks. ISRA International Journal of Islamic Finance 11: 282-302. [CrossRef]

Husin, Maizaitulaidawati Md, Noraini Ismail, and Asmak Ab Rahman. 2016. The roles of mass media, word of mouth and subjective norm in family takaful purchase intention. Journal of Islamic Marketing 7: 59-73. [CrossRef]

Ibrahim, Mohamed Dahlan, Fauzilah Salleh, and Zainudin Awang. 2015. The Effects of Financial Factors on Takaful Demand in Malaysia. Journal of Entrepre neurship and Business 3: 17-29. [CrossRef]

Ibrahim, Nur Izzati, Amirul Afif Muhamat, Azreen Roslan, and Mohamad Nizam Jaafar. 2020. Determinants of composite takaful operators' financial performance. Global Business \& Management Research 12: 331-36.

ICRS. 2012. Bangladesh: Islamic Welfare Organisation Trained in Dead Body Identification. From International Committee of the Red Cross. Available online: https://www.icrc.org/eng/resources/documents/feature/2012/bangladesh-feature-2012-07-03.htm (accessed on 21 February 2018).

Jalil, Abdullaah. 2006. The Significances of Maslahah Concept and Doctrine of Maqasid (Objectives) Al-Shariah in Project Evaluation. The Journal of Muamalat and Islamic Finance Research 3: 171-202.

Kantakji, Mazhar Hallak, Baharom Abdul Hamid, and Syed Othman Alhabshi. 2020. What drives the financial performance of general takaful companies? Journal of Islamic Accounting and Business Research 11: 1301-22. [CrossRef]

Khan, Hayat. 2019. A Nontechnical guide on optimal incentives for Islamic insurance operators. Journal of Risk and Financial Management 12: 127. [CrossRef]

Kim, Karl, and Jennifer Davidson. 2015. Unmanned Aircraft Systems Used for Disaster Management. Transportation Research Record 2532: 83-90. [CrossRef]

Knaul, Felicia Marie, Paul E. Farmer, Eric L. Krakauer, Liliana De Lima, Afsan Bhadelia, Xiaoxiao Jiang Kwete, Héctor Arreola-Ornelas, Octavio Gómez-Dantés, Natalia M. Rodriguez, George A. O. Alleyne, and et al. 2018. The Lancet Commissions Alleviating the access abyss in palliative care and pain relief-an imperative of universal health coverage: The Lancet Commission report. The Lancet 391: 1391-454. [CrossRef]

Lee, Kok Ming. 2020. Cost-Benefit Analysis. Available online: http:/ / kokminglee.125mb.com/economics/costbenefit.html (accessed on 30 November 2020).

Levin, Henry M., and Patrick J. McEwan. 2001. Cost-Effectiveness Analysis: Methods and Applications. Thousand Oaks: Sage.

Lewis, Mervyn K., and Latifa M. Algaoud. 2001. Islamic Banking. Cheltenham: Edward Elgar.

Malaysia Insurance. 2018. Top Ten 2017 Claims Trend Likely to Impact 2018. Malaysia Insurance Online. Available online: http: / / www.malaysiainsurance.info/top-ten-2017-claims-trend-likely-to-impact-2018/ (accessed on 6 April 2021).

Manaf, Azwina Wati Abdull, and Norazuan Amiruddin. 2019. Fintech and the challenge of digital disruption in takaful operation. Asia Proceedings of Social Sciences 4: 1-3. [CrossRef]

Mansour, Walid, Khoutem Ben Jedidia, and Jihed Majdoub. 2015. How ethical is Islamic banking in the light of the objectives of Islamic law? Journal of Religious Ethics 43: 51-77. [CrossRef] 
Marsh, Kevin, Ceri J. Phillips, Richard Fordham, Evelina Bertranou, and Janine Hale. 2012. Estimating cost-effectiveness in public health: A summary of modelling and valuation methods. Health Economics Review 2: 17. [CrossRef]

Merriam, Sharan B., and Robin S. Grenier. 2019. Qualitative Research in Practice: Examples for Discussion and Analysis. Hoboken: John Wiley \& Sons.

Merriam, Sharan B., and Elizabeth J. Tisdell. 2016. Qualitative Research: A Guide to Design and Implementation. San Fransisco: Jossey-Bass.

Muhamat, Amirul Afif, and Ronald McIver. 2019. Linking governance qualities and stewardship attributes: Findings from Malaysian takaful operators. Journal of Islamic Accounting and Business Research 10: 736-55. [CrossRef]

Muhamat, Amirul Afif, Mohamad Nizam Jaafar, and Sharifah Faigah Syed Alwi. 2017. General takaful claims: An experience of takaful operator in Malaysia. Journal of Emerging Economies and Islamic Research 5: 18-26. [CrossRef]

Muhamat, Amirul Afif, Siti Nurhidayah Sulaiman, and Mohamad Nizam Jaafar. 2018. Determinants of Claims for Takaful Householder and Houseowner Policies. Journal of Wealth Management E Financial Planning 5: 25-36.

Muhamat, Amirul Afif, Mohamad Nizam Jaafar, and Mohd Samsuri Mood Saad. 2019. Essential Components of Takaful Operation. Durian Tunggal: Penerbit UTeM.

NICE. 2013. Guide to the Methods of Technology Appraisal 2013. London: National Institute for Health and Clinical Excellence (NICE).

Penuel, K. Bradley, Matthew Statler, and Ryan Hagen. 2013. Encyclopedia of Crisis Management. Thousand Oaks: Sage.

Reich, Lia. 2016. How Drones Are Being Used in Disaster Management? Available online: https://geoawesomeness.com/drones-flyrescue/ (accessed on 13 August 2021).

Reuters. 2014. Record Numbers Evacuated in Malaysia's Worst Floods in Decades. Available online: https://www.reuters.com/article/ malaysia-floods/record-numbers-evacuated-in-malaysias-worst-floods-in-decades-idUSL3NOUA12Z20141226 (accessed on 13 August 2021).

Reuters. 2017. How Allstate and Farmers Insurance Will Use Drones to Assess Damage from Hurricane Harvey. Available online: /fortune.com/2017/08/30/hurricane-harvey-drones-insurance/ (accessed on 6 April 2021).

Rubio-Misas, Maria. 2020. Financial stability in markets with a dual system of takaful companies and conventional insurers. Pacific-Basin Finance Journal 62: 101355. [CrossRef]

Saad, Muhammad Aizat, and Wan Nazjmi Mohamed Fisol. 2019. Financial technology (FinTech) services: Analysis from the perspective of maqāṣid al-Shariah. Journal of Social Science and Humanities 2: 6-11.

Saba, Irum. 2017. Islamic Finance: Local and Global Status. In Developments in Islamic Finance: Challenges and Initiatives. Edited by Syed Aun Rizvi and Irum Saba. Karachi: Springer, pp. 1-20.

Shmat, Darya. 2018. Taking to the Skies-Using Drones in the Insurance Industry. IDG Communications. Available online: https: / / www.cio.com/paper/3252093/taking-to-the-skies-using-drones-in-the-insurance-industry.html (accessed on 4 April 2021).

Siddiqi, M. Fahad, Shafiullah Jan, and Karim Ullah. 2019. Maqasid al Shariah and stakeholders' wellbeing in Islamic banks: A proposed framework. Business E Economic Review 11: 83-102.

Terrance, C. Luciani, Barbara A. Distasio, John Bungert, and Matt Summer. 2016. Use of Drones to Assist with Insurance, Financial and Underwriting Related Activities. Available online: http:/ / www.freepatentsonline.com/y2016/0063642.html (accessed on 30 May 2021).

The Treasury of New Zealand. 2015. Guide to Social Cost Benefit Analysis. Wellington: The Treasury New Zealand.

Yin, Robert K. 2018. Case Study Research and Applications. Los Angeles: Sage.

Zainul, Emir. 2018. Fitch: Malaysia's Takaful Growth Continued to Outpace Conventional Insurance in 1H17, The Edge Markets. Available online: https://www.theedgemarkets.com/paper/fitch-malaysias-takaful-growth-continued-outpace-conventionalinsurance-1h17 (accessed on 30 May 2021). 